\title{
THE INTERNATIONAL ECONOMICS OF NATURAL RESOURCES AND GROWTH
}

\author{
THORVALDUR GYLFASON
}

CESIFO WORKING PAPER NO. 1994

CATEGORY 8: RESOURCES AND ENVIRONMENT

MAY 2007

An electronic version of the paper may be downloaded

- from the SSRN website:

wWw.SSRN.com

- from the RePEc website:

www.RePEc.org

- from the CESifo website:

www.CESifo-group.de 


\title{
THE INTERNATIONAL ECONOMICS OF NATURAL RESOURCES AND GROWTH
}

\begin{abstract}
This article is in three parts. First, it briefly describes the contribution of natural resources to economic growth around the world, pondering the question whether an abundance of natural resources is a blessing or a curse. Second, an attempt is made to provide a glimpse of recent empirical evidence that can be brought to bear on this question. Third, the article discusses the experience of Norway, the world's third largest oil exporter. To date, Norway has appeared to be mostly free of the worrisome symptoms, such as the Dutch disease, that have afflicted many other countries with abundant natural resources.
\end{abstract}

JEL Code: O11.

Thorvaldur Gylfason

Faculty of Economics and Business Administration

University of Iceland

101 Reykjavik

Iceland

gylfason@hi.is

This article is drawn from the author's keynote lecture at a conference on Sustainable resource management, raw materials security, Factor- $X$ resource productivity - tools for delivering sustainable growth in the European Union organized by the College of Europe and held in Bruges, Belgium, 6-7 December 2006. 


\section{Introduction}

There was a time when economic geography was a popular subject that was widely taught at universities in Europe and elsewhere. Importantly, the old economic geography was the study of raw materials and their distribution around the world and it assigned a key role to natural resource wealth and raw materials and their ownership and trade routes. There was a tendency among economic geographers as well as in public consciousness to equate the ownership of those important resources with economic strength. Yet, today, as we know, many resource-abundant countries are in dire straits for reasons that seem to be related in part to poor management of their natural resources, while several resource-poor countries have become rich. President Vladimir Putin of Russia has described this well: "Our country is rich, but our people are poor." Unsurprisingly, therefore, the new economic geography puts less emphasis on natural resources by recognizing several distinct sources of wealth, not least the accumulation of human capital, for there are many different kinds of capital and, accordingly, many separate sources of economic growth. In his memoirs, Lee Kuan Yew, the founding father of Singapore (1959-1991), described this as follows:

I thought then that wealth depended mainly on the possession of territory and natural resources, whether fertile land ..., or valuable minerals, or oil and gas. It was only after I had been in office for some years that I recognized ... that the decisive factors were the people, their natural abilities, education and training. ${ }^{1}$

So how do countries grow rapidly? What does it take? Recent economic growth theory suggests several key factors:

(a) Saving and investment to build up real capital - physical infrastructure, roads and bridges, factories, machinery, equipment, and such;

(b) Education, training, health care, and social security to build up human capital, a better and more productive work force;

(c) Exports and imports of goods, services, and capital to build up foreign capital, among other things, to supplement domestic capital;

(d) Democracy, freedom, and honesty - that is, absence of corruption - to build up social

\footnotetext{
${ }^{1}$ Quoted from Lee Kuan Yew (1998), The Singapore Story, Memoirs of Lee Kuan Yew, Singapore Press Holdings, Singapore.
} 
capital, to strengthen the social fabric, the glue that helps hold the economic system together and keep it in good running order;

(e) Economic stability with low inflation to build up financial capital - in other words, liquidity - that lubricates the wheels of the economic system and helps keep it running smoothly; and

(f) Manufacturing and service industries that permit diversification of the national economy away from excessive reliance on low-skill-intensive primary production, including agriculture, based on natural capital.

The above enumeration could be extended, of course, but let us rather notice three things that need to be noticed about this short list.

First, capital appears in many different guises, some tangible, some not, but in all its guises it needs to be built up gradually through painstaking investments at the expense of current consumption. A strong capital base requires a lot of good and durable investments in different areas.

In second place, natural capital differs from the other kinds of capital on the list in that it may be a good idea - for reasons to be discussed as we proceed - to be on guard against excessive reliance on this particular kind of capital. Here it is important to distinguish clearly between natural resource abundance and natural resource dependence. By abundance is meant the amount of natural capital that a country has at its disposal: mineral deposits, oil fields, forests, land, and the like. By dependence is meant the extent to which the nation in question depends on these natural resources for its livelihood. Some countries with abundant natural resources, for example, Australia, Canada, and the United States, outgrew those resources and are no longer especially dependent on them. Other resource-abundant countries, for example, the Organization of Petroleum Exporting Countries (OPEC), do depend on their resources, some practically for all they have got. Still other countries, say, Chad and Mali, have few resources and yet depend on them for the bulk of their export earnings because they have little else to offer for sale abroad. Others still have few resources and do not depend in any important manner on the little they have, such as, for example, Jordan and Panama. The idea that diversification away from natural resources may be good for long-run growth centers on dependence rather than abundance even if the distinction 
may in some instances be hard to make in practice. The working hypothesis here is that excessive dependence on a few natural resources may hurt economic growth, even if an abundance of natural resources, if well managed, may be good for growth.

Third, economic diversification encourages growth by attracting economic activity from excessive reliance on primary production in agriculture or a few natural-resource-based industries, thus facilitating the transfer of labor from low-paying jobs in low-skill-intensive farming or mining to more lucrative jobs in more high-skill-intensive occupations. Political diversification discourages growth in a similar way by redistributing political power from ruling elites to the people, thus in many cases replacing an extended monopoly of often illgotten power by democracy and pluralism. The basic argument is the same in both cases: diversity is good for growth. Modern mixed economies need a broad base of manufacturing, trade, and services to be able to offer the people a steadily improving standard of living. Therefore, they need to find ways of diversifying their economic activity away from oncedominant agriculture that tends to perpetuate poverty and similarly away from too much dependence on a few natural resources that tend to stifle or delay the development of modern manufacturing and services. To function well, national economies also need broad political participation and a broad base of power in order to be able to offer the citizenry an efficient and fair way of exercising its political will and civic rights through free assembly, elections, and such. Without political democracy, bad governments tend to last too long and do too much damage. The need for diversification is especially urgent in resource-rich countries because they often face a double jeopardy - that is, natural resource wealth that is concentrated in the hands of relatively small groups that seek to preserve their own privileges by standing in the way of both economic and political diversification that would disperse their power and wealth. Rent-seekers typically resist reforms - economic diversification as well as democracy - that would redistribute the rents to their rightful owners. $^{2}$

This article is divided in three parts. First, I want to consider the contribution of natural resources to economic growth around the world and whether an abundance of natural resources is a blessing or a curse. Second, I want to try to provide a brief glimpse of the

\footnotetext{
${ }^{2}$ See Richard M. Auty (2001), "The Political Economy of Resource-Driven Growth," European Economic Review 45, May, 839-846, and Michael Ross (2001) “Does Oil Hinder Democracy?,” World Politics 53, April, 325-361.
} 
empirical cross-country evidence that can be brought to bear on this question. Third, I want to consider the recent experience of Norway, the world's third largest oil exporter, a country that thus far has appeared to be mostly free of the worrisome symptoms, including the Dutch disease, that have afflicted many other natural-resource-rich countries.

\section{Six separate sources of growth}

Figure 1 describes how the six different types of capital listed in Section 1 impact economic growth (arrows 1-6).

- Arrow 1 refers to the effect of real capital formation on economic growth. To be conducive to rapid growth, investment must be sufficient in quantity as well as of high quality. Unfortunately, investment figures in national income accounts do not distinguish good investments from bad ones. Even so, empirical evidence suggests that investment, unadjusted for quality, makes an important contribution to economic growth. It seems reasonable to surmise that the link between quality-adjusted investment, if such information were available country by country, and growth would be even stronger.

- Arrow 2 describes the contribution of education to economic growth. Education and onthe-job training improve the labor force and thus enable workers to use existing capital more efficiently and they also tend to speed up the rate of technological progress, thus encouraging growth. However, increased human capital may reduce the need for further accumulation of real capital as witnessed by declining rates of investment with increased education in industrial countries since 1960. Thus, human capital crowds out real capital. Again, quantity does not automatically guarantee quality. Most available and commonly used measures of education - school-enrolment rates, years of schooling, and expenditure on education, for example - reflect education inputs rather than outputs, quantity rather than quality. Yet, empirical evidence suggests that increased education is associated with more rapid growth across countries.

- Arrow 3 describes the contribution of financial capital to economic growth. The extent of liquidity represented by the ratio of money, broadly defined, to Gross Domestic Product (GDP) reflects the financial maturity of a country, or financial depth: the more mature a country's financial markets - that is, the better the markets can serve their core function of channeling household savings into high-quality investments - the higher will be the 
rate of long-run economic growth, other things being the same. High inflation punishes people and firms for holding cash, and thus deprives the economic system of essential lubrication and slows down economic growth.

- Arrow 4 refers to the effect of the influx of foreign capital on economic growth. Foreign capital spurs growth by supplementing domestic capital as well as by imparting new ideas, skills, and expertise to the receiving country.

- Arrow 5 refers to the contribution of social capital to economic growth. For our purposes, it is perhaps most useful to think of social capital in terms of those aspects of a country's political and social infrastructure that matter most for economic growth. For example, corruption in government and business, rampant rent seeking by pressure groups, and political oppression all tend to distort the allocation of resources, impair efficiency, and reduce economic growth. ${ }^{3}$ Such activity can be viewed as corrosion of social capital. Similarly, a lack of social cohesion bred by excessive inequalities in the distribution of incomes and wealth may create animosities and conflicts among social groups that impede economic efficiency and growth, again by corroding social capital. Social capital and human capital are closely related. Increased education may reduce society's tolerance of great disparities of income and wealth and thus spur growth through increased social as well as human capital. At the same time, excessive inequality may trigger demands for more and better education that increases growth.

- Arrow 6 describes the direct effect of natural resource wealth on economic growth. Countries with abundant natural resources experience booms and busts at regular intervals due to commodity price fluctuations in world markets as well as to resource discoveries that typically create intermittent upswings in export earnings that cause the national currency to appreciate in real terms to the detriment of other export industries. This happened in the Netherlands in the early 1960s following the discovery of large reserves of natural gas within Dutch jurisdiction in the North Sea. The Dutch actually got over this ailment before long, so today the Dutch disease is a misnomer, but the name stuck. Many other countries suffer from the Dutch disease through misaligned and volatile exchange rates. This idea is derived from recent empirical research, initiated by

\footnotetext{
${ }^{3}$ See Pranab Bardhan (1997), "Corruption and Development: A Review of the Issues," Journal of Economic Literature 35, September, 1320-1346.
} 
Sachs and Warner. ${ }^{4}$ This research has uncovered a strong and robust inverse crosscountry relationship between economic growth and the abundance of, or rather dependence on, natural resources. As many observers still find this result surprising, or at least counter-intuitive, it may be worthwhile to devote a bit more space to this recently rediscovered determinant of growth (arrow 6) and the various channels through which it works than to the less controversial determinants sketched above (arrows 1-5). This brings us to Figure 2 that describes five additional channels through which natural resource dependence can affect long-run economic growth across countries (arrows 7-11).

First, resource-rich countries tend to be marred by rent seeking on the part of producers who thus divert resources from more socially fruitful economic activity. ${ }^{5}$ In particular, the combination of abundant natural resource rents, ill-defined property rights, imperfect or missing markets, and lax legal structures may have quite destructive consequences. In extreme cases, civil wars break out - Africa's diamond wars, for example - and divert factors of production from socially productive uses and weaken or destroy societal institutions and the rule of law. In other, less extreme cases, the struggle for huge resource rents may lead to a concentration of economic and political power in the hands of elites that, once in power, use the rent to placate their political supporters and secure their hold on power, with stunted or weakened democracy and slow growth as a result. Rent seeking can also take other, more subtle forms. Governments may be tempted to thwart markets by granting favored enterprises or individuals privileged access to common-property natural resources. Extensive rent seeking - that is, seeking to make money from market distortions - can breed corruption in business and government, thus distorting the allocation of resources and reducing both economic efficiency and social equality. Insofar as natural resource dependence involves public allocation of access to scarce common-property resources to private parties without payment, thereby essentially leaving the resource rent up for grabs, it is only to be expected that resource-rich countries may be more susceptible to corruption than others. Further, natural resource abundance may fill people with a false sense of security and lead governments to lose sight of the need for good and growth-friendly

\footnotetext{
${ }^{4}$ See Jeffrey D. Sachs and Andrew M. Warner (1995, revised 1997, 1999), “Natural Resource Abundance and Economic Growth," NBER Working Paper 5398, Cambridge, Massachusetts.

${ }^{5}$ See Richard M. Auty (ed.) (2001), Resource Abundance and Economic Development, Oxford University Press, Oxford and New York.
} 
economic management, including free trade, bureaucratic efficiency, and institutional quality. Incentives to create wealth through sound policies and institutions may wane because of the relatively effortless ability to extract wealth from the soil or the sea. Manna from heaven can be a mixed blessing. Furthermore, natural capital may crowd out social capital by increasing income inequality if natural resource rents tend to be less equally distributed than labor income among the population. Indeed, if this is not so at the time of the resource discovery, then the chief purpose of the ensuing rent-seeking activity is precisely to produce such an outcome. Some of the most resource-rich countries in the world are also among the least egalitarian. Arrow 7 describes the effects of natural resources on economic growth through rent seeking, corruption, and inequality all of which tend to corrode social capital and reduce growth.

Second, natural capital may crowd out human capital as well as social capital by weakening education (arrow 8). Specifically, abundant natural resources may weaken private and public incentives to accumulate human capital. Awash in cash, natural-resource-rich nations may be tempted to underestimate the long-run value of education. Of course, the rent stream from abundant natural resources may enable nations to give a high priority to education - as in Botswana, for instance, where government expenditure on education relative to national income is among the highest in the world. ${ }^{6}$ Even so, empirical evidence shows that, across countries, school enrolment at all levels is inversely related to natural resource dependence. There is also evidence that, across countries, public expenditures on education relative to national income, expected years of schooling, and school enrolment are all inversely related to natural resource dependence. ${ }^{7}$ This matters because more and better education is good for growth.

Third, abundant natural resources may likewise blunt private and public incentives to save and invest and thereby slow down economic growth (arrow 9). Specifically, when the share of output that accrues to the owners of natural resources rises, the demand for capital

\footnotetext{
${ }^{6}$ See Daron Acemoglu, Simon Johnson, and James A. Robinson (2003), „An African Success Story: Botswana,“ Chapter 4 in Dani Rodrik, In Search of Prosperity: Analytical Narratives of Economic Growth, Princeton University Press, Princeton, New Jersey.

${ }^{7}$ See Thorvaldur Gylfason (2001), “Natural Resources, Education, and Economic Development," European Economic Review 45, May, 847-859.
} 
falls, so that real interest rates also go down and growth subsides. ${ }^{8}$ In other words, natural capital may crowd out real capital as well as human capital and social capital. As in the case of education, the quality - that is, efficiency - of investment must also make a big difference. Unproductive investments may seem unproblematic to governments or individuals who are flush with cash thanks to nature's bounty. Most of the oil-rich OPEC countries have grown remarkably slowly since the 1960s despite a large volume of investment relative to GDP.

Fourth, when a large part of national wealth is stored in a natural resource, there may be less need for financial intermediation to conduct day-to-day transactions (arrow 10). Consumption can be financed through more rapid depletion of the natural resource and saving can take place through less rapid depletion or of more rapid renewal if the resource is renewable. In some countries, such as the OPEC states, a significant part of domestic saving is transferred abroad and stored in foreign bank deposits or other assets. In this case, domestic financial intermediation becomes even less important. In contrast, when saving is piled up at home in the form of physical capital, domestic banks and financial markets assume paramount importance. By building bridges between domestic savers and investors, the domestic financial system contributes to a more efficient allocation of capital across sectors and firms. So, if an abundance of, or dependence on, natural resource wealth tends to hamper the development of the financial system and hence to distort the allocation of capital, economic growth may slow down due to the detrimental effect of financial backwardness on saving and investment. Therefore, natural resource dependence tends to retard the development of financial institutions and hence discourage saving, investment, and economic growth. Natural capital can crowd out financial capital.

Fifth, arrow 11 in Figure 2 suggests that natural resource dependence may discourage foreign capital inflows as well as exports and thus reduce openness. This point follows directly from the discussion above surrounding arrow 6 in Figure 1 and arrow 7 in Figure 2. The Dutch disease manifests itself through reduced incentives to produce nonprimary goods and services for export which the overvalued currency of the resource-rich country renders uncompetitive at world market prices. This reduces trade. Rent-seeking domestic producers demand protection against foreign competition, for example in the form of restrictions

\footnotetext{
${ }^{8}$ See Thorvaldur Gylfason and Gylfi Zoega (2006), “Natural Resources and Economic Growth: The Role of Investment," World Economy 29, August, 1091-1115.
} 
against foreign direct investment. Natural capital may thus crowd out foreign capital. This form of the Dutch disease - from natural resource riches to foreign capital controls - needs closer scrutiny in future research. This possibility matters because openness to foreign trade and investment is almost surely good for growth.

There is one last thing to consider. Because natural resources are a fixed factor of production, at least if they are nonrenewable, they impose, almost by definition, a restriction on economic growth potential. This restriction is likely to cause a growing labor force as well as a growing stock of real capital to exhibit diminishing returns. The long-run rate of growth of per capita output in an economy with natural resources can be shown to be proportional to the rate of technological progress adjusted for a "population growth drag" due to diminishing returns as well as a "natural resource depletion drag" due to declining levels of exhaustible natural resources. ${ }^{9}$

\section{Cross-country evidence}

Against the road map laid out in Section 2, let us now look at some cross-sectional empirical evidence covering 85 countries in the period 1965-1998. Two thirds of the countries in the sample are developing countries; the remaining ones are industrial countries. All the data used in this article are from the World Bank, ${ }^{10}$ with the exception of the index of political liberty (see below). The sample is confined to 85 of the 92 countries for which the World Bank has compiled data on natural capital in 1994, until recently the sole year for which such data were available. ${ }^{11}$ Six countries could not be included because of missing data and one, Saudi Arabia, because its economic growth statistics are quite volatile. ${ }^{12}$ The empirical strategy here is to relate the rate of growth of per capita gross national product (GNP) to its main long-term determinants, that is, to measures of investment in different kinds of capital.

\footnotetext{
${ }^{9}$ Nordhaus, William D. (1992), “Lethal Model 2: The Limits to Growth Revisited," Brookings Papers on Economic Activity 2, 1-43.

${ }^{10}$ See World Bank (2000), World Development Indicators 2000, World Bank, Washington, D.C. See also World Bank (1997), "Expanding the Measure of Wealth: Indicators of Environmentally Sustainable Development," Environmentally Sustainable Development Studies and Monographs Series No. 17, World Bank, Washington, D.C.

${ }^{11}$ Data on natural capital in 2000 have recently become available. See World Bank (2006), Where Is the Wealth of Nations? Measuring Capital for the 21st Century, World Bank, Washington, D.C.

${ }^{12}$ For a list of the countries and a description of the data, see reference in footnote 8.
} 
Specifically, the idea is to look for evidence of cross-country linkages among resource dependence, resource abundance, and economic growth in the context of the recent empirical growth literature.

We begin by making a couple of spot checks in order to allow the data to speak for themselves. ${ }^{13}$ Figure 3 shows the relationship between average annual per capita growth of GNP from 1965 to 1998 and the share of natural capital in national wealth, our proxy for natural resource dependence (recall Figure 1, arrow 6). National wealth is defined as the sum of real capital, human capital, and natural capital, but does not include financial capital, foreign capital, and social capital. ${ }^{14}$ In view of the possibility that poor countries grow more rapidly than rich because they are catching up, the growth variable on the vertical axis has been purged of that part of growth that can be explained by the country's initial income per head. ${ }^{15}$ In Figure 3, each country is represented by one two-dimensional observation or bubble whose area is proportional to the country's size as measured by its average population from 1965 to 1998. A decrease in the natural capital share by eight percent of national wealth is associated with an increase in per capita growth by one percent per year, a significant relationship in an economic sense even if at this stage nothing is said about cause and effect. The Spearman rank correlation is -0.64 , which is highly significant in a statistical sense. This result is consistent with arrows 6-11 in Figures 1 and 2.

Notice now the two clusters in the southeast corner and the northwest corner of Figure 3. The southeast corner is occupied by eight natural-resource-dependent, slow-growth African countries whose average investment 1965-1998 amounted to 14 percent of GDP. In the northwest corner we have Botswana, ${ }^{16}$ Mauritius, and six other natural-resource-poor, highgrowth countries in Asia whose average investment ratio was almost twice as high, or 27 percent of GDP, in the same period. This pattern accords well with a linkage between natural resource dependence and growth through investment (arrow 9). Further, the first (African)

\footnotetext{
${ }^{13}$ This discussion draws on Thorvaldur Gylfason (2002), “Mother Earth: Ally or Adversary?,” World Economics 3, January-March, 7-24.

${ }^{14}$ See the second reference in footnote 10.

${ }^{15}$ This was done by first regressing per capita growth on the logarithm of initial income per head (i.e., in 1965) as well as on the share of natural capital in national wealth and then subtracting the initial income component from the observed growth rate.

${ }^{16}$ Botswana's natural capital share is small in Figure 3 because the World Bank does not provide an estimate the country's diamond rent. The inclusion of Botswana in the sample does not materially influence any of the empirical results presented in this paper.
} 
cluster of countries sent 12 percent of its adolescents to secondary school during 1965-1997 compared with 54 percent for the second (Asian) cluster. This is consistent with a linkage between natural resource dependence and growth through education (arrow 8). Further still, the first cluster of countries attracted foreign direct investment equivalent to 0.5 percent of GDP during 1975-1998 while the second cluster attracted three times as much foreign investment, equivalent to 1.5 percent of GDP. This suggests a linkage between natural resource dependence and growth through openness (arrow 11). There is more: with a Gini index of 54 on average, the first cluster of countries has a much less equal distribution of income than the second cluster, where the Gini index is 37 on average. This suggests a linkage between natural resource dependence and growth through inequality (arrow 7). At last, with broad money equivalent to 16 percent of GDP on average from 1965 to 1998 , the first (African) cluster of countries has less financial depth than the second (Asian) cluster, where the broad money/GDP ratio was almost three times as high, or 47 percent on average over the same period. This is consistent with a linkage between natural resource dependence and growth through financial depth (arrow 10).

Next, consider social capital, or rather one important aspect thereof, namely, political liberty. In Figure 4, per capita growth, measured as before, is shown on the vertical axis and an index of political liberties, borrowed from political scientists, ${ }^{17}$ appears on the horizontal axis (recall Figure 1, arrow 5). The political liberties index ranges from one (unfettered political liberties) to seven (negligible political liberties). Hence, an increase in the index means less liberty. Figure 4 shows a clear cross-country relationship between political liberty and economic growth from 1965 to 1998 . The regression line through the scatter plot in the figure suggests that an decrease of about two points in the political liberties index (i.e., increased liberty) goes along with an increase in per capita growth from one country to another by one percentage point per year on average. The relationship is significant economically as well as statistically (the rank correlation is 0.62 ), and conforms to the partial correlations that have been reported in multiple regression analyses where other relevant determinants of growth (investment, education, etc., as well as initial income) are taken into

\footnotetext{
${ }^{17}$ The political liberties index is an average for the years 1972-1990 and is taken from Adam Przeworski, Michael E. Alvarez, José Antonio Cheibub, and Fernando Limongi (2000), Democracy and Development: Political Institutions and Well-Being in the World, 1950-1990, Cambridge University Press, Cambridge.
} 
account, as we will proceed to do below. Figure 4 thus accords with the view that democracy is good for growth and vice versa: there is no visible sign here that democracy stands in the way of economic growth. Political liberty is good for growth because oppression stifles creativity and innovation and thus breeds inefficiency. China, as you can see, is the big outlier in the northeastern corner of the figure. Elsewhere I have presented pictures of the remaining relationships corresponding to arrows $1-4$ in Figure $1 .^{18}$

We now take the next step and estimate a series of growth regressions for the same 85 countries as before, again during 1965-1998. The strategy here is to regress the rate of growth of per capita GNP during this 33-year period on the share of natural capital in national wealth, defined as in Figure 3, and then to add other potential determinants of growth to the regression in order to assess the robustness of the initial result - that is, to see if natural capital survives the introduction of additional explanatory variables that are commonly used in empirical growth research.

Table 1 presents the resulting sequence of regressions. In accordance with Figure 3, Model 1 shows a statistically significant bivariate relationship between the natural capital share in national wealth, our proxy for natural resource dependence as in Figure 3, and per capita growth. When natural capital per person, our proxy for natural resource abundance, is added to the regression in Model 2, we see that natural resource dependence continues to hurt growth as hypothesized, even if natural resource abundance has a positive, albeit insignificant, effect on growth. In Model 3, the logarithm of initial income (i.e., in 1965) is added to capture conditional convergence - the idea that rich countries grow less rapidly than poor ones because the rich have already exploited more of the growth opportunities available to them, by sending more young people to school, for instance. Initial income is defined as purchasing-power-parity adjusted per capita GNP in 1998 divided by an appropriate growth factor to ensure consistency between our income measures in 1965 and 1998 and our measures of economic growth between those years. Here we see that the coefficient on initial income is significantly negative as expected. The resource dependence variable survives and the resource abundance variable is resuscitated. Next, in Model 4, we add political liberty to the regression. We see that political liberty is good for growth in accordance with Figure 4 and all the preceding variables survive. In Model 5, we add the

\footnotetext{
${ }^{18}$ See reference in footnote 13.
} 
share of gross domestic investment in GDP and find that it makes a contribution to growth as expected, even if no attempt has been made to adjust the investment figures for quality. In Model 6, we then proceed to add education, represented by the secondary-school enrolment rate, the measure of education most commonly used in empirical growth research. Like investment, education stimulates growth without displacing any of the variables inherited from the preceding models. At last, in Model 7, we enter population growth into the regression to see if it matters for growth as suggested by the neoclassical growth model. We see that increased population growth hurts economic growth as expected, without reducing the statistical significance of the explanatory variables already included. Specifically, it takes an increase in annual population growth of less than two percentage points to reduce per capita growth by one percentage point. This suggests a significant population drag on growth. Moreover, reduced population growth enables parents to take better care of each of their children and thus to increase their average "quality" by offering each one of them more and better education, health care, and other opportunities and amenities that the parents otherwise could not afford. Viewed this way, reduced fertility is a form of investment in human capital, intended to increase the quality and efficiency of the labor force.

The bottom line of Table 1 shows how the adjusted $R^{2}$ rises gradually as more explanatory variables are added to the growth regression and ultimately reaches 0.74 , indicating that Model 7 explains almost three fourths of the cross-country variations in the long-run rate of growth of per capita output.

The results from Model 7 accord reasonably well with a number of recent empirical growth studies. In Model 7, the coefficient on initial income suggests a conditional convergence speed of almost two percent per year, which is not significantly below the two to three percent range typically reported in econometric growth research. The coefficient on the investment rate suggests that an increase in investment by ten percent of GDP increases annual per capita growth by one percentage point, a typical result in those growth studies that report a statistically significant effect of investment on growth. The coefficient on the education variable in Model 6 means that an increase in secondary-school enrolment by a half of each cohort (e.g., from 25 percent to 75 percent) increases per capita growth by one percentage point. Last but not least, the coefficient on the natural resource dependence 
variable suggests that an increase in the share of natural capital in national wealth by 12 percentage points reduces per capita growth by one percentage point, even if natural resource abundance may at the same time be good for growth. Beginning with Sachs and Warner, ${ }^{19}$ several recent studies have reported a broadly similar conclusion about the effect of natural resource dependence on growth, based on various measures of the natural resource variable.

Table 1. Regression Results on Natural Resources and Economic Growth

\begin{tabular}{|c|c|c|c|c|c|c|c|}
\hline & Model 1 & Model 2 & Model 3 & Model 4 & Model 5 & Model 6 & Model 7 \\
\hline Natural capital & $\begin{array}{l}-0.09 \\
(5.6)\end{array}$ & $\begin{array}{l}-0.10 \\
(5.9)\end{array}$ & $\begin{array}{l}-0.15 \\
(8.6)\end{array}$ & $\begin{array}{l}-0.12 \\
(7.3)\end{array}$ & $\begin{array}{l}-0.09 \\
(5.8)\end{array}$ & $\begin{array}{l}-0.07 \\
(5.0)\end{array}$ & $\begin{array}{l}-0.08 \\
(5.5)\end{array}$ \\
\hline $\begin{array}{l}\text { Natural capital } \\
\text { per person }\end{array}$ & & $\begin{array}{l}0.03 \\
(1.6)\end{array}$ & $\begin{array}{l}0.09 \\
(4.7)\end{array}$ & $\begin{array}{l}0.07 \\
(3.2)\end{array}$ & $\begin{array}{l}0.05 \\
(2.6)\end{array}$ & $\begin{array}{l}0.04 \\
(2.0)\end{array}$ & $\begin{array}{l}0.04 \\
(2.6)\end{array}$ \\
\hline Initial income & & & $\begin{array}{l}-1.03 \\
(5.3)\end{array}$ & $\begin{array}{l}-1.54 \\
(7.4)\end{array}$ & $\begin{array}{l}-1.34 \\
(6.8)\end{array}$ & $\begin{array}{l}-1.93 \\
(9.1)\end{array}$ & $\begin{array}{r}-1.89 \\
(9.2)\end{array}$ \\
\hline Political liberty & & & & $\begin{array}{l}-0.50 \\
(4.5)\end{array}$ & $\begin{array}{l}-0.43 \\
(4.2) \\
\end{array}$ & $\begin{array}{l}-0.33 \\
(3.6) \\
\end{array}$ & $\begin{array}{l}-0.28 \\
(3.2) \\
\end{array}$ \\
\hline Investment & & & & & $\begin{array}{l}0.10 \\
(4.2) \\
\end{array}$ & $\begin{array}{l}0.07 \\
(2.8) \\
\end{array}$ & $\begin{array}{l}0.08 \\
(3.5) \\
\end{array}$ \\
\hline $\begin{array}{l}\text { Secondary } \\
\text { education }\end{array}$ & & & & & & $\begin{array}{l}0.04 \\
(4.8)\end{array}$ & $\begin{array}{l}0.02 \\
(2.4)\end{array}$ \\
\hline $\begin{array}{l}\text { Population } \\
\text { growth }\end{array}$ & & & & & & & $\begin{array}{l}-0.54 \\
(2.8) \\
\end{array}$ \\
\hline Adjusted $\mathrm{R}^{2}$ & 0.26 & 0.28 & 0.45 & 0.56 & 0.64 & 0.71 & 0.74 \\
\hline
\end{tabular}

Note: $\mathrm{t}$-values are shown within parentheses. Estimation method: Ordinary least squares. Number of countries: 85 . No outliers were excluded.

In sum, we have seen that natural capital influences economic growth in two ways. On the one hand, an increase in the share of natural capital in national wealth reduces economic growth. On the other hand, an increase in natural capital per person stimulates growth. Because natural capital per person equals, by definition, the multiple of the share of natural capital in national wealth and wealth per person, Table 1 suggests that the total effect of an

\footnotetext{
${ }^{19}$ See reference in footnote 4.
} 
increase in the natural capital share on economic growth is -0.08 plus 0.05 times wealth per person (in hundreds of thousands of US dollars). Therefore, the total effect of an increase in the natural capital share on growth declines with wealth per person but remains negative as long as national wealth per capita is below USD $200,000\left(=0.08 / 0.04 \times 10^{5}\right)$. For comparison, the cut-off point between the 20 industrial countries and 65 developing countries in the sample is roughly USD 150,000. This means that an increase in the natural capital share tends to reduce growth in developing countries, but may increase growth in industrial countries. These results can be supplemented by tracing the additional effects of increased natural capital on real capital via blunted incentives to save and invest; on human capital through neglect of education; on social capital via rent seeking, civil and political oppression, corruption, and so forth, on financial capital through failure to develop institutions; and on foreign capital through protectionism along the lines laid out in Section $2 .^{20}$

\section{Norway}

The list of natural-resource-abundant countries beset by economic and political difficulties is a long one, but it does not include Norway, the third largest oil exporter in the world after Saudi-Arabia and Russia. As I have emphasized in the preceding sections, the problem under review is not the existence of natural wealth as such but rather the failure to avert the dangers that accompany the gifts of nature. Norway has charted a long-run-oriented, taxbased approach to the management of its vast oil resources. By law, the title to petroleum deposits on the Norwegian continental shelf is vested in the State. Thus, all the rent from oil and gas should accrue to the Norwegian people through their government. This constitutes the legal basis for government regulation of the petroleum sector as well as for its taxation. Exploration and production licenses are awarded for a small fee to domestic and foreign oil companies alike. It was decided to expropriate the oil and gas rent through taxes and fees as well as direct involvement in the development of the resources rather than through sales or auctioning of exploration and production rights. Through its direct partnership with licensees as well as through various taxes and fees, the Norwegian State has managed to absorb about 80 percent of the resource rent since 1980. The oil revenue is deposited in the Government

\footnotetext{
${ }^{20}$ See references in footnotes 7 and 8.
} 
Pension Fund (the name was recently changed; before the change, it was called the Norwegian Petroleum Fund). The fund is currently about USD 300 billion, or about USD 65,000 per person, and is divided between mostly foreign bonds (two thirds) and equities (one third). As the name change suggests, the fund is intended to benefit the current generation of Norwegians in old age as well as future generations. Another aim has been to shield the domestic economy from overheating and possible waste. Even so, a variable proportion of each year's net oil-tax revenue is transferred to the government budget, essentially to cover the non-oil budget deficit. The Norwegians have not been tempted to expand their central government beyond reasonable limits as a result of the oil boom. Even 30 years after discovering their oil, the Norwegians have a smaller central government than Denmark and Sweden next door. As soon as the Bank of Norway was made, by law, more independent from political interference a few years ago, the management of the oil fund was transferred from the Ministry of Finance to the Bank to increase the distance between the politicians and the fund, a shrewd move.

Norway's tradition of democracy since long before the advent of oil has probably helped immunize the country from the ailments that afflict most other oil-rich nations. Large-scale rent seeking has been averted in Norway, investment performance has been adequate, and the country's education record is excellent. The proportion of each cohort attending colleges and universities in Norway rose from 26 percent in 1980 to 80 percent in 2003. Even so, Norway faces challenges. Some (weak) signs of the Dutch disease can be detected, notably sluggish exports and foreign direct investment and the absence of a large, vibrant high-tech manufacturing industry as in Sweden and Finland next door. Norway's lack of interest in joining the European Union and in undertaking difficult but necessary reforms - in health care provision, for instance - may be the other side of the same coin. But perhaps the main challenge is to make sure that the oil wealth does not instill a false sense of security, a feeling that anything goes and that difficult decisions can be deferred or avoided. Hence the effort to immunize the fund from political interference by handing its management over to an independent central bank. Another possibility would be privatization, by, for example, turning the oil fund over to the people in the form of pension savings. Yet another solution might be to invest the authority to dispose of the oil revenues in a special independent, yet democratically accountable and fully transparent authority. A mixed strategy could also be 
envisaged, with shared public and private responsibility for the disposal of the oil wealth to spread the risks and reconcile different points of view.

\section{Conclusion}

Good times demand strong discipline. Natural resources bring risks, including a false sense of security that may lead people to underrate or overlook the need for good policies and institutions, good education, and good investment. Awash in easy cash, they may find that hard choices perhaps can be avoided, or at least deferred. Awareness of these risks is perhaps the best insurance policy against them.

Nothing is new under the sun. David Landes, the economic historian, tells the story of Spain following the colonization of South and Central America which made Spain rich in gold and other natural resources. He concludes: "Easy money is bad for you. It represents shortrun gain that will be paid for in immediate distortions and later regrets." ${ }^{21}$

\footnotetext{
${ }^{21}$ See David S. Landes (1998), The Wealth and Poverty of Nations, W. W. Norton \& Co., New York and London,
} 171. 


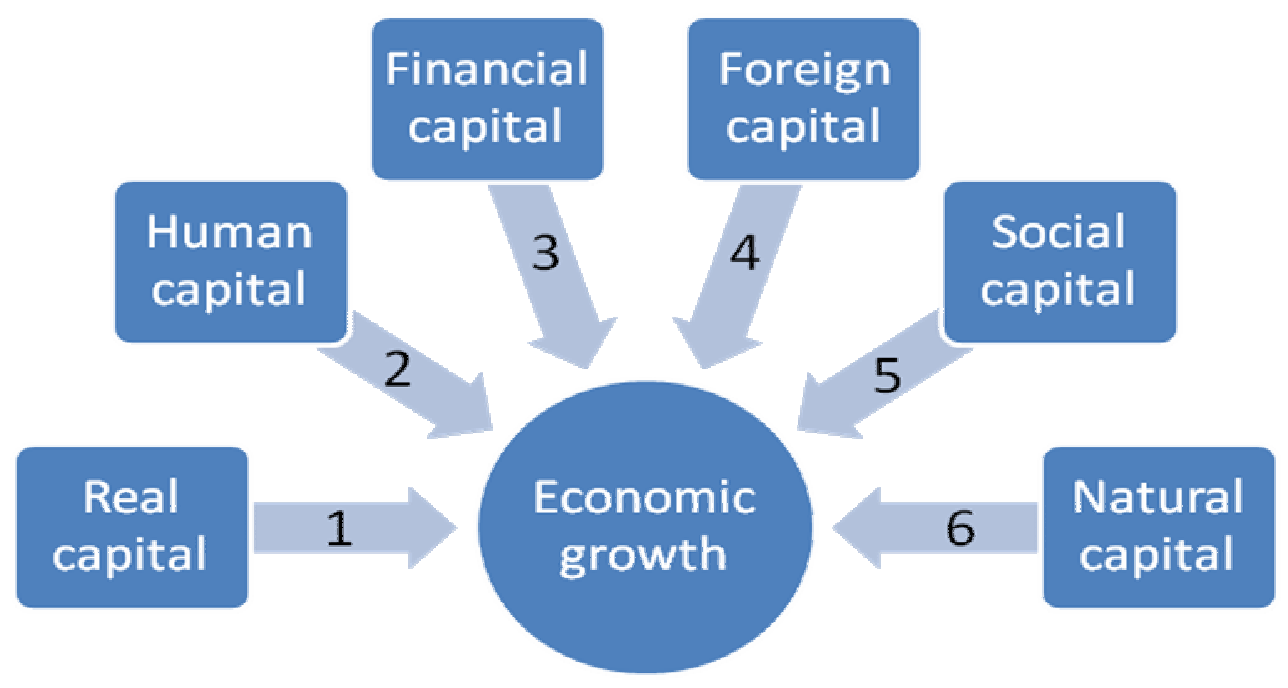

Figure 1. Different Kinds of Capital and Growth

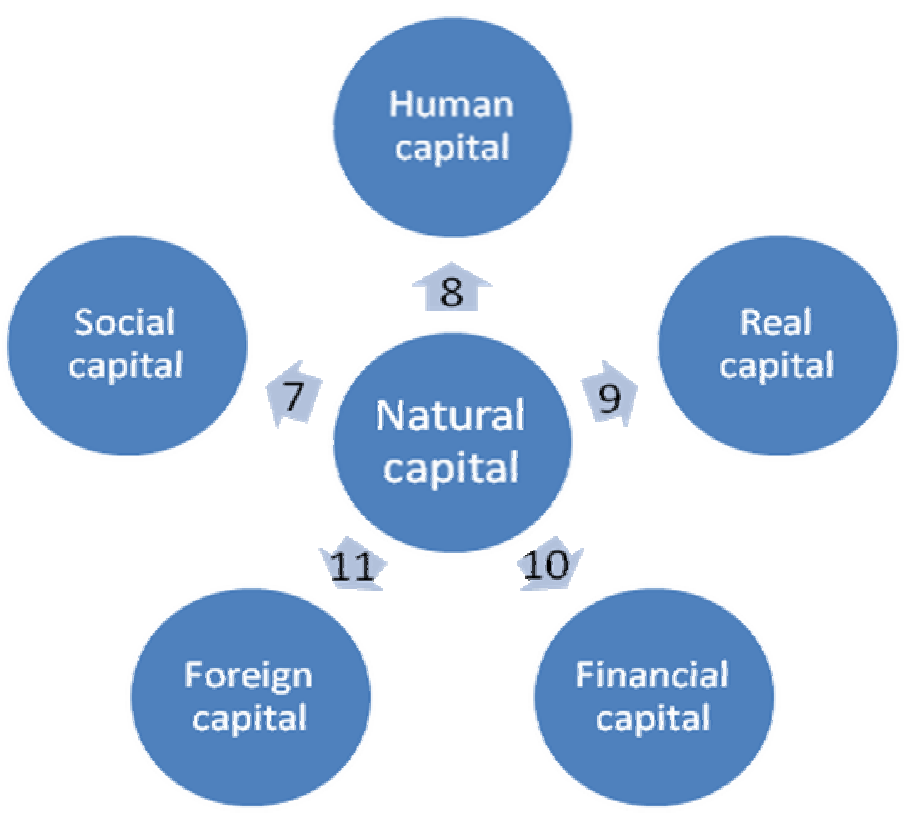

Figure 2. Natural Capital and Other Kinds of Capital 


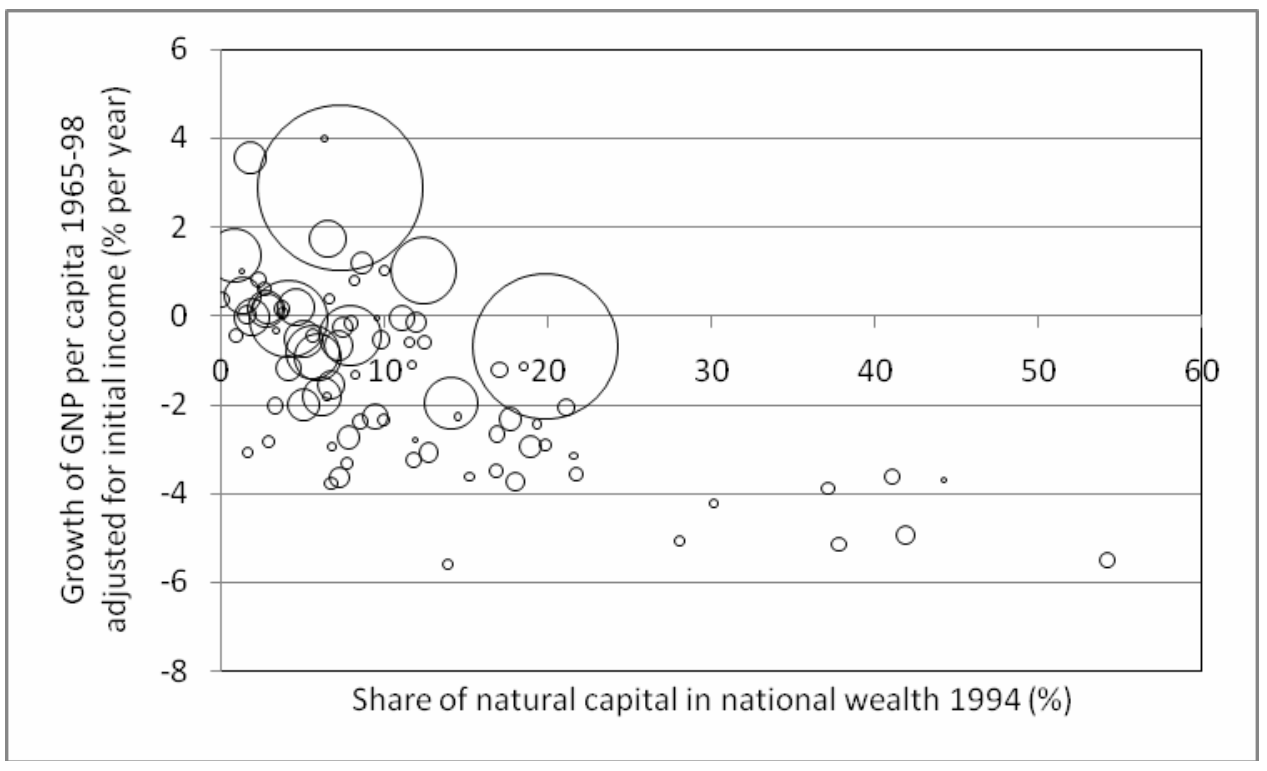

Figure 3. Natural Capital and Economic Growth

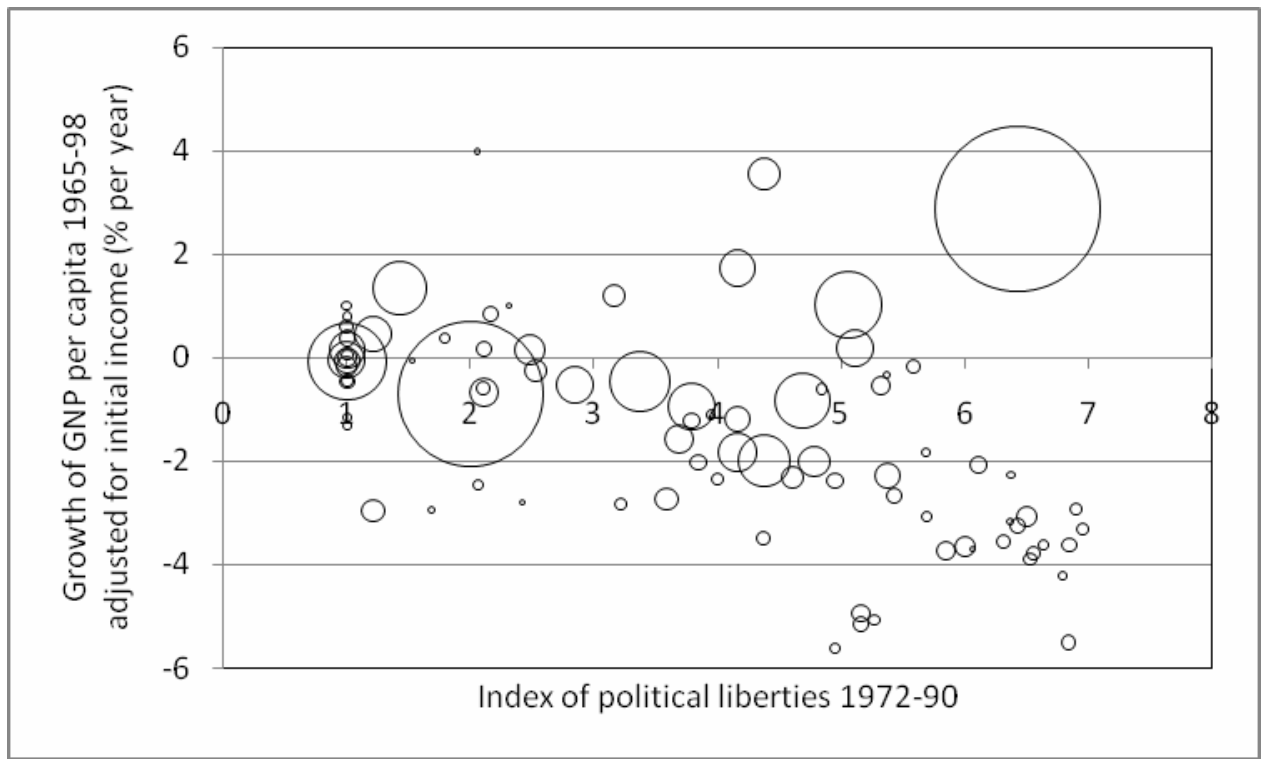

Figure 4. Political Liberty and Economic Growth 


\section{CESifo Working Paper Series}

(for full list see www.cesifo-group.de)

1928 Balázs Égert, Kirsten Lommatzsch and Amina Lahrèche-Révil, Real Exchange Rates in Small Open OECD and Transition Economies: Comparing Apples with Oranges?, February 2007

1929 Aleksander Berentsen and Cyril Monnet, Monetary Policy in a Channel System, February 2007

1930 Wolfgang Ochel, The Free Movement of Inactive Citizens in the EU - A Challenge for the European Welfare State?, February 2007

1931 James K. Hammitt and Nicolas Treich, Statistical vs. Identified Lives in Benefit-Cost Analysis, February 2007

1932 Wilhelm Kohler, The Bazaar Effect, Unbundling of Comparative Advantage, and Migration, February 2007

1933 Karsten Staehr, Fiscal Policies and Business Cycles in an Enlarged Euro Area, February 2007

1934 Michele Bernasconi and Paola Profeta, Redistribution or Education? The Political Economy of the Social Race, March 2007

1935 Axel Dreher, Martin Gassebner and Lars-H. R. Siemers, Does Terror Threaten Human Rights? Evidence from Panel Data, March 2007

1936 Naércio Aquino Menezes Filho and Marc-Andreas Muendler, Labor Reallocation in Response to Trade Reform, March 2007

1937 Gebhard Flaig and Timo Wollmershaeuser, Does the Euro-zone Diverge? A Stress Indicator for Analyzing Trends and Cycles in Real GDP and Inflation, March 2007

1938 Michael Funke and Michael Paetz, Environmental Policy Under Model Uncertainty: A Robust Optimal Control Approach, March 2007

1939 Byeongchan Seong, Sung K. Ahn and Peter A. Zadrozny, Cointegration Analysis with Mixed-Frequency Data, March 2007

1940 Monika Bütler and Michel André Maréchal, Framing Effects in Political Decision Making: Evidence from a Natural Voting Experiment, March 2007

1941 Giacomo Corneo and Olivier Jeanne, A Theory of Tolerance, March 2007

1942 Qing Hong and Michael Smart, In Praise of Tax Havens: International Tax Planning and Foreign Direct Investment, March 2007 
1943 Yin-Wong Cheung, Dickson Tam and Matthew S. Yiu, Does the Chinese Interest Rate Follow the US Interest Rate?, March 2007

1944 Panu Poutvaara and Mikael Priks, Unemployment and Gang Crime: Could Prosperity Backfire?, March 2007

1945 Burkhard Heer, On the Modeling of the Income Distribution Business Cycle Dynamics, March 2007

1946 Christoph A. Schaltegger and Lars P. Feld, Are Fiscal Adjustments less Successful in Decentralized Governments?, March 2007

1947 Giovanni Facchini, Marcelo Olarreaga, Peri Silva and Gerald Willmann, Substitutability and Protectionism: Latin America's Trade Policy and Imports from China and India, March 2007

1948 C. Mirjam van Praag and Bernard M. S. van Praag, The Benefits of Being Economics Professor A (and not Z), March 2007

1949 Astrid Hopfensitz and Frans van Winden, Dynamic Choice, Independence and Emotions, March 2007

1950 Guglielmo Maria Caporale and Luis A. Gil-Alana, A Multivariate Long-Memory Model with Structural Breaks, March 2007

1951 Mattias Ganslandt and Keith E. Maskus, Wholesale Price Discrimination and Parallel Imports, March 2007

1952 Michela Redoano, Fiscal Interactions Among European Countries. Does the EU Matter?, March 2007

1953 Stefan C. Wolter, Rémy Hübschi and Matthias Müller, Push or Pull? An Empirical Analysis of the Demand for Individual Project Grants from the Swiss National Science Foundation, March 2007

1954 Scott Alan Carson, African-American and White Inequality in the American South: Evidence from the $19^{\text {th }}$ Century Missouri State Prison, March 2007

1955 Peter Egger, Marko Koethenbuerger and Michael Smart, Do Fiscal Transfers Alleviate Business Tax Competition? Evidence from Germany, March 2007

1956 Panu Poutvaara and Lars-H. R. Siemers, Smoking and Social Interaction, March 2007

1957 Stephan Danninger and Fred Joutz, What Explains Germany's Rebounding Export Market Share?, March 2007

1958 Stefan Krasa and Mattias Polborn, Majority-efficiency and Competition-efficiency in a Binary Policy Model, March 2007 
1959 Thiess Buettner and Georg Wamser, Intercompany Loans and Profit Shifting Evidence from Company-Level Data, March 2007

1960 Per Pettersson-Lidbom and Mikael Priks, Behavior under Social Pressure: Empty Italian Stadiums and Referee Bias, April 2007

1961 Balázs Égert and Carol S. Leonard, Dutch Disease Scare in Kazakhstan: Is it real?, April 2007

1962 Paul De Grauwe and Pablo Rovira Kaltwasser, Modeling Optimism and Pessimism in the Foreign Exchange Market, April 2007

1963 Volker Grossmann and Thomas M. Steger, Anti-Competitive Conduct, In-House R\&D, and Growth, April 2007

1964 Steven Brakman and Charles van Marrewijk, It's a Big World After All, April 2007

1965 Mauro Ghinamo, Paolo M. Panteghini and Federico Revelli, FDI Determination and Corporate Tax Competition in a Volatile World, April 2007

1966 Inés Macho-Stadler and David Pérez-Castrillo, Optimal Monitoring to Implement Clean Technologies when Pollution is Random, April 2007

1967 Thomas Eichner and Ruediger Pethig, Efficient $\mathrm{CO}_{2}$ Emissions Control with National Emissions Taxes and International Emissions Trading, April 2007

1968 Michela Redoano, Does Centralization Affect the Number and Size of Lobbies?, April 2007

1969 Christian Gollier, Intergenerational Risk-Sharing and Risk-Taking of a Pension Fund, April 2007

1970 Swapan K. Bhattacharya and Biswa N. Bhattacharyay, Gains and Losses of India-China Trade Cooperation - a Gravity Model Impact Analysis, April 2007

1971 Gerhard Illing, Financial Stability and Monetary Policy - A Framework, April 2007

1972 Rainald Borck and Matthias Wrede, Commuting Subsidies with two Transport Modes, April 2007

1973 Frederick van der Ploeg, Prudent Budgetary Policy: Political Economy of Precautionary Taxation, April 2007

1974 Ben J. Heijdra and Ward E. Romp, Retirement, Pensions, and Ageing, April 2007

1975 Scott Alan Carson, Health during Industrialization: Evidence from the $19^{\text {th }}$ Century Pennsylvania State Prison System, April 2007

1976 Andreas Haufler and Ian Wooton, Competition for Firms in an Oligopolistic Industry: Do Firms or Countries Have to Pay?, April 2007 
1977 Eckhard Janeba, Exports, Unemployment and the Welfare State, April 2007

1978 Gernot Doppelhofer and Melvyn Weeks, Jointness of Growth Determinants, April 2007

1979 Edith Sand and Assaf Razin, The Role of Immigration in Sustaining the Social Security System: A Political Economy Approach, April 2007

1980 Marco Pagano and Giovanni Immordino, Optimal Regulation of Auditing, May 2007

1981 Ludger Woessmann, Fundamental Determinants of School Efficiency and Equity: German States as a Microcosm for OECD Countries, May 2007

1982 Bas Jacobs, Real Options and Human Capital Investment, May 2007

1983 Steinar Holden and Fredrik Wulfsberg, Are Real Wages Rigid Downwards?, May 2007

1984 Cheng Hsiao, M. Hashem Pesaran and Andreas Pick, Diagnostic Tests of Cross Section Independence for Nonlinear Panel Data Models, May 2007

1985 Luis Otávio Façanha and Marcelo Resende, Hierarchical Structure in Brazilian Industrial Firms: An Econometric Study, May 2007

1986 Ondřej Schneider, The EU Budget Dispute - A Blessing in Disguise?, May2007

1987 Sascha O. Becker and Ludger Woessmann, Was Weber Wrong? A Human Capital Theory of Protestant Economic History, May 2007

1988 Erkki Koskela and Rune Stenbacka, Equilibrium Unemployment with Outsourcing and Wage Solidarity under Labour Market Imperfections, May 2007

1989 Guglielmo Maria Caporale, Juncal Cunado and Luis A. Gil-Alana, Deterministic versus Stochastic Seasonal Fractional Integration and Structural Breaks, May 2007

1990 Cláudia Costa Storti and Paul De Grauwe, Globalization and the Price Decline of Illicit Drugs, May 2007

1991 Thomas Eichner and Ruediger Pethig, Pricing the Ecosystem and Taxing Ecosystem Services: A General Equilibrium Approach, May 2007

1992 Wladimir Raymond, Pierre Mohnen, Franz Palm and Sybrand Schim van der Loeff, The Behavior of the Maximum Likelihood Estimator of Dynamic Panel Data Sample Selection Models, May 2007

1993 Fahad Khalil, Jacques Lawarrée and Sungho Yun, Bribery vs. Extortion: Allowing the Lesser of two Evils, May 2007

1994 Thorvaldur Gylfason, The International Economics of Natural Resources and Growth, May 2007 